\title{
Investigation of Natural Infection by Leishmania in Sandflies of Paraná State, Southern Brazil
}

\author{
Regiane Bertin de Lima Scodro ${ }^{1}$, Kárin Rosi Reinhold-Castro ${ }^{1}$, Alessandra de Cassia Dias- \\ Sversutti $^{2}$, Herintha Coeto Neitzke-Abreu ${ }^{2}$, Norberto de Assis Membrive ${ }^{3}$, João Balduíno \\ Kühl $^{4}$, Thaís Gomes Verzignassi Silveira ${ }^{4}$ and Ueslei Teodoro ${ }^{4 *}$ \\ ${ }^{1}$ Universidade Estadual de Maringá; Programa de Pós-Graduação em Análises Clínicas ${ }^{2}$; Programa de Pós- \\ Graduação em Ciências da Saúde $;^{3}$ Núcleo de Entomologia Médica da Secretaria de Saúde do Paraná; Arapongas, \\ Paraná, Brazil. ${ }^{4}$ Departamento de Análises Clínicas da Universidade Estadual de Maringá; Avenida Colombo \\ 5790; 87020-900; uteodoro@uem.br; Maringá - PR - Brazil
}

\begin{abstract}
The purpose of this work was to verify the occurrence of Leishmania in naturally infected sandflies. The insects were collected with Falcão, Shannon and HP light-traps, in Doutor Camargo and Maringá municipalities between November 2004 and October 2005. Of the 11,033 sandflies collected in Doutor Camargo, 2,133 surviving females were dissected, particularly those of the Nyssomyia neivai species (86.87\%). In Maringá, 136 sandflies were collected, of which $79 \mathrm{~N}$. whitmani females and 1 Migonemyia migonei female were dissected. The dissected insects were identified and stored in the pools of 10 specimens. The PCR was carried out on 1,190 females of N. neivai and 190 of $N$. whitmani from Doutor Camargo, and on 30 of $N$. whitmani from Maringá, using the primers MPIL/MP3H. The natural infection by Leishmania in sandflies was not confirmed by either of the methods used. The results suggested the low natural infection rate of sandflies by Leishmania in these areas, corroborating other studies carried out in endemic areas of ACL.
\end{abstract}

Key words: Cutaneous leishmaniasis, sandflies, dissection, polymerase chain reaction

\section{INTRODUCTION}

Leishmaniasis are diseases transmitted by the vectors and present a high degree of the complexity in terms of ecology and epidemiology (WHO, 2005). It is estimated that there are 12 million people infected around the world, with approximately 600,000 new cases notified per year (WHO, 2005). The majority (90\%) of the cases of the cutaneous leishmaniasis occur in the Middle East (Iran, Saudi Arabia, Syria, Afghanistan) and in South America (Bolivia, Peru and Brazil) (WHO, 2005). In the last 20 years, the cutaneous leishmaniasis has increased in Latin America, particularly in Brazil (Armijos et al., 1997, King et al., 2004; Ministério da Saúde, 2005). In Brazil, 552,059 cases of the American cutaneous leishmaniasis (ACL) were reported between 1980 and 2003, of which 12,304 (2.2\%) occurred in the Southern region, with $12,220(99.3 \%)$ of them in the Paraná State (Lima et al., 2002; Ministério da Saúde, 2005).

Studies carried out in the north of Paraná showed that the species Migonemyia migonei (França), Nyssomyia whitmani (Antunes and Coutinho), Pintomyia pessoai (Coutinho and Barretto),

\footnotetext{
${ }^{*}$ Author for correspondence
} 
Pintomyia fischeri (Pinto) and Nyssomyia neivai (Pinto) were always present and could be of importance in the epidemiology of ACL (Membrive et al., 2004; Teodoro et al., 2001a; 2003a; 2003b; 2004). In the Americas, the transmission cycle of Leishmania involves only a few of the approximately 460 species of the sandfly existing in the region (Aguiar and Medeiros, 2003). The detection and identification of the species of Leishmania in naturally infected sandflies are important for the prevention of the disease in the endemic areas (Kato et al., 2005). The infection rate in the naturally infected vectors in the endemic areas and the correct identification of the etiologic agent are of great importance in the epidemiology of the leishmaniasis (Michalsky et al., 2002). Luz et al., (2002) confirmed, for the first time, the infection of $N$. whitmani by $L e$. braziliensis in the State of Paraná, showing the necessity of new studies to detect the natural infection in other species of the sandfly that might be involved in the epidemiology of the ACL in the state.

In the last ten years, the molecular techniques have been used in the detection and identification of Leishmania in the culture, biopsy, scrapes, blood and sandflies (Michalsky et al., 2002). However, the most frequently used method of verifying the infection in the sandflies by the flagellates is the observation of the content of the digestive tract of the insect by dissection (Michalsky et al., 2002). After isolation, the parasite is inoculated into the hamsters or in vitro in the culture medium for the identification of the species.

In Recanto Marista, Doutor Camargo municipality, where 10 human cases of ACL were registered in 1996, diverse measures for the control of the sandfly population have been carried out with some success (Teodoro et al., 2001a; 2003a). However, the sandfly population continues to be dense specially in the hen houses, constructed deliberately to attract them, thus preventing direct contact with the inhabitants of the area (Teodoro et al., 2001a; 2003a). In Parque do Ingá, Maringá municipality, the infection of two night wardens was confirmed. The areas mentioned host some species of the wild mammals, potential reservoirs of Leishmania, making the existence of an enzootic cycle of Leishmania possible. $N$. neivai is dominant in Recanto Marista and N. whitmani in Parque do Ingá. In these localities the population of these species has been increasing (Teodoro et al., 2001a; 2003a; 2003b). Therefore, this study aimed at verifying the occurrence of the sandflies naturally infected by Leishmania by means of dissection and polymerase chain reaction (PCR).

\section{MATERIALS AND METHODS}

\section{Areas of study}

The study was carried out in Doutor Camargo and Maringá municipalities, both in the Central North Mesoregion of the Paraná. Recanto Marista is located in the municipality of Doutor Camargo (52 $13^{\prime}$ ' West and $23^{\circ} 33^{\prime}$ 'South), on the banks of the Ivaí river in an area of 41 hectares of greatly altered residual forest. The Parque do Ingá, located in the urban area of Maringá municipality $\left(51^{\circ} 25^{\prime}\right.$ West and $23^{\circ} 25^{\prime}$ 'South), is a 47.4-hectares area of preserved pristine forest. In these two areas where the research project was carried out, the forests are of transitional type from the dense tropical to the subtropical, with the presence of some deciduous species and mild droughts occurring during the winter. In these municipalities, the annual average precipitation is $1,700 \mathrm{~mm}$. The driest months are June, July, August and the rainiest are December, January and February.

\section{Sandfly collection}

In Doutor Camargo, the collections were carried out in December 2004, January, February, March, May, June, July, August, September and October 2005 in the peridomicile, interior of the forest and in the hen houses from 8 p.m. to midnight, giving a total of 304 hours of collection. In Maringá, the collections were carried out in November and December 2004, and August 2005 at the edge of the forest near wild animal shelters from 7 p.m. to 11 p.m. to a total of 40 hours of collection. The collections were carried out with Falcão, Shannon and HP light-traps (Pugedo et al., 2005).

\section{Dissection and identification}

The insects were dissected at the place of the capture or in the Laboratory of Entomology of the Department of Clinical Analysis of Maringá State University. The dissection for the observation of the natural infection by Leishmania was carried out by the technique used by Lainson (1997), with some modifications. The females were dissected under a stereoscope, using the minute needles on the slides washed with $2 \%$ sodium hypochlorite and disinfected with $70 \%$ alcohol. Two drops of the saline $(0.9 \%)$ were placed on each slide: the 
legs and wings of the female were removed in one of the drops and the dissection was carried out in the other by making two incisions in the distal portion of the abdomen and, with zigzag movements, the digestive tract removed, the whole being covered with a cover-slip and examined under optical microscope $(400 \mathrm{x})$ for the identification of the species of the sandfly and the search for the flagellates. The female sandflies were identified by the observation of the spermathecae, palps and other morphological characters. The dissection for verification of the infection was only carried out on live females because of the difficulty of performing the procedure after the sandfly was dead for a long time. The insects dissected were conserved in the tubes containing the absolute alcohol (Cabrera et al., 2002). Each tube contained 10 digestive tracts. The nomenclature of the sandfly species followed Galati (2003).

\section{DNA extraction}

The alcohol in the tubes was evaporated in a dry bath (BIOPLUS IT-2002) at $95^{\circ} \mathrm{C}$ and the extraction of the DNA was carried out by guanidine-phenol method (Chomczynski and Sacchi, 1987), modified as follows: $300 \mu \mathrm{L}$ of isothiocyanate of guanidine-phenol solution was added to the sandfly pools, which were homogenized for 1 minute and then $50 \mu \mathrm{L}$ of chloroform were added with gentle shaking. After centrifugation at $9,200 \mathrm{~g}$ for 10 minutes, the supernatant was transferred to another tube containing $300 \mu \mathrm{L}$ of the absolute ethanol, which was shaken for 1 minute and centrifuged at 9,200g for 15 minutes. The sediment was then washed with $300 \mu \mathrm{L}$ of the absolute ethanol with centrifugation at $9,200 \mathrm{~g}$ for 10 minutes. The supernatant was discarded and the sediment was dried in a dry bath at $95^{\circ} \mathrm{C}$. The DNA sediment was hydrated in $50 \mu \mathrm{L}$ of TE buffer (Tris-base $10 \mathrm{mM}, \mathrm{pH} 8.0 ; \mathrm{Na}_{2}$ EDTA- $\mathrm{H}_{2} \mathrm{O} 1 \mathrm{mM}, \mathrm{pH} 8.0$ ), incubated in a tube homogenizer for 6 hours at room temperature and stored at $4^{\circ} \mathrm{C}$ until use. For each of the 22 samples submitted to DNA extraction, 1 negative control (male sandfly) and 1 positive control (female sandfly + Le. braziliensis promastigotes) were used.

\section{Polymerase chain reaction}

For the DNA amplification, MP1L (5' - TAC TCC CCG ACA TGC CTC TG - 3') and MP3H (5' -
GAA CGG GGT TTC TGT ATG C - 3') primers were used, as described by Lopez et al., (1993), which amplified a fragment of $70 \mathrm{bp}$ of the minicircle region present in the kDNA of members of the Leishmania (Viannia) subgenus. The reaction mixture $(25 \mu \mathrm{L})$ was prepared containing the final concentration of $1 \mu \mathrm{M}$ of each primer (Invitrogen ${ }^{\circledR}$ ), $0.2 \mathrm{mM}$ dNTP (Invitrogen $®$ ), $2 \mathrm{U}$ of Taq DNA Polymerase (Invitrogen $®$ ), $3 \mathrm{mM}$ of $\mathrm{MgCl}_{2}$, enzyme buffer and $5 \mu \mathrm{L}$ of DNA. The DNA amplification was performed in a Thermocycler Personal Cycler (Biometra) using initial heating of $95^{\circ} \mathrm{C}$ for 5 minutes. Later, thirty cycles were carried out, each of them divided into three stages: denaturation $\left(95^{\circ} \mathrm{C}-1.5\right.$ minutes $)$, annealing $\left(56^{\circ} \mathrm{C}-1.5\right.$ minutes $)$ and polymerization $\left(72^{\circ} \mathrm{C}-2\right.$ minutes). Then, the material was maintained at $72^{\circ} \mathrm{C}$ for 10 minutes and the amplified product was stored at $4^{\circ} \mathrm{C}$ until its analysis. The amplified products were analyzed by the electrophoresis in 3\% agarose gel stained with ethidium bromite $0.1 \mu \mathrm{g} / \mathrm{mL}$ at $100 \mathrm{~V}$ during 20 minutes. Negative and positive controls were used at all the stages of the amplification. The products of the amplification were visualized under the ultraviolet light in a transilluminator (MacroVue UV-20 Hoefer).

\section{Assay of sensitivity}

The males were grouped into tubes (containing 10 sandflies each), to which different amounts (20,000, 2,000, 200, 20 and 2) of Le. braziliensis promastigotes, cultivated in 199 medium and washed in PBS, were added.

\section{RESULTS}

Table 1 showed that from the Recanto Marista, 11,033 sandflies (7,959 females and 3,074 males), representing the following five species, were collected: N. neivai, $N$. whitmani, $P$. fischeri, $M$. migonei, $P$. pessoai, Evandromyia cortelezzii (Brèthes) and Pintomyia monticola (Costa Lima). The predominant species were $N$. neivai, with 8,926 specimens $(80.90 \%)$, and $N$. whitmani, with $2,044(18.52 \%)$. The other species represented less than 1\%. In Parque do Ingá, 136 sandflies (81 females and 55 males) were collected, belonging to the species $N$. whitmani and M. migonei, with the former predominating $(98.75 \%)$. From the total of 2,133 dissected females, 1,853 were $N$. neivai, 
265 N. whitmani, 9 P. fischeri, 5 P. pessoai and 1 E. cortelezzii (Table 2). Of the dissected females, $624(29.25 \%)$ were collected in the hen houses. In Parque do Ingá, 80 females were dissected, 79 being $N$. whitmani and $1 \mathrm{M}$. migonei (Table 2). The natural infection by Leishmania was not seen in any of the dissected females.

The PCR (extraction by guanidine-phenol and amplification with primers MP1L/MP3H) detected
20 parasites per sandfly (Fig. 1A). It was carried out on 1,190 females of $N$. neivai and 190 of $N$. whitmani, collected in the Recanto Marista and 30 females of $N$. whitmani, collected from the Parque do Ingá. The female sandflies submitted to the PCR did not reveal the presence of the DNA of any member of the Leishmania (Viannia) subgenus (Fig. 1B).

Table 1 - Sandflies caught from the Doutor Camargo (Recanto Marista) and Maringá (Parque do Ingá) municipalities.

\begin{tabular}{lcccccc}
\hline & \multicolumn{3}{c}{ Recanto Marista } & \multicolumn{3}{c}{ Parque do Ingá } \\
\cline { 2 - 7 } Species & Female & Male & Total & Female & Male & Total \\
\hline Nyssomyia neivai & 6,386 & 2,540 & 8,926 & 0 & 0 & 0 \\
Nyssomyia whitmani & 1,542 & 502 & 2,044 & 80 & 52 & 132 \\
Pintomyia fischeri & 17 & 21 & 38 & 0 & 0 & 0 \\
Pintomyia pessoai & 8 & 3 & 11 & 0 & 0 & 0 \\
Migonemyia migonei & 4 & 8 & 12 & 1 & 3 & 4 \\
Pintomyia monticola & 1 & 0 & 1 & 0 & 0 & 0 \\
Evandromyia cortelezzii & 1 & 0 & 1 & 0 & 0 & 0 \\
\hline Total & 7,959 & 3,074 & 11,033 & 81 & 55 & 136 \\
\hline
\end{tabular}

Table 2 - Female sandflies dissected to verify the natural infection by Leishmania from the Doutor Camargo (Recanto Marista) and Maringá (Parque do Ingá) municipalities.

\begin{tabular}{|c|c|c|c|c|}
\hline \multirow[t]{2}{*}{ Species } & \multicolumn{2}{|c|}{ Recanto Marista } & \multicolumn{2}{|c|}{ Parque do Ingá } \\
\hline & $\mathrm{N}$ & $\%$ & $\mathrm{~N}$ & $\%$ \\
\hline Nyssomyia neivai & 1,853 & 86.87 & 0 & 0 \\
\hline Nyssomyia whitmani & 265 & 12.42 & 79 & 98.75 \\
\hline Pintomyia fischeri & 9 & 0.42 & 0 & 0 \\
\hline Pintomyia pessoai & 5 & 0.23 & 0 & 0 \\
\hline Migonemyia migonei & 0 & 0 & 1 & 1.25 \\
\hline Evandromyia cortelezzii & 1 & 0.05 & 0 & 0 \\
\hline Total & 2,133 & 100.00 & 80 & 100.00 \\
\hline
\end{tabular}

\section{DISCUSSION}

The species collected from the Recanto Marista and Parque do Ingá have been previously described in these locations (Teodoro et al., 2001a; 2003b). The predominant species in Recanto Marista was $N$. neivai $(80.90 \%)$, followed by $N$. whitmani $(18.52 \%)$, while in Parque do Ingá, $N$. whitmani predominated $(98.75 \%)$. No sandfly specimen was found to be infected by Leishmania, either on the dissection or PCR at the locations studied. The PCR is a highly sensitive technique, confirmed by Pita-Pereira et al., (2005) and
Michalsky et al., (2002), who detected the presence of one and ten parasites per sandfly, respectively. These results were similar to those found in this study, employing the extraction by the guanidine-phenol and amplification with the primers MP1L/MP3H, which detected 20 parasites per sandfly. The lower sensitivity observed could be attributed to possible interference due to the contents of the insects' digestive tracts, an observation previously made by Aransay et al., (2000). 
In spite of the fact that the ACL is endemic in Paraná State, the investigation of the sandfly infection rate in the state has been neglected. The first isolation and identification of Le. braziliensis in sandflies was carried out by Luz et al., (2002), in the city of Cambira in the north of Paraná, who found $3(0.18 \%) N$. whitmani females naturally infected by Le. braziliensis, out of a total of 1,612 female sandflies dissected. The low infection rate was attributed to the low parasite pressure. It is important to remember that in Paraná State, the parasites isolated in the majority of cases of human and canine ACL have been identified as Le. braziliensis (Lonardoni et al., 1993; Silveira et al.,
1999). The PCR has been widely used in the study of the natural and experimental sandfly infection, using various primers (Pérez et al., 1994; Rodriguez et al., 1999; Aransay et al., 2000; Michalsky et al., 2002; Miranda et al., 2002; PitaPereira et al., 2005; Kato et al., 2005; Jorquera et al., 2005). According to Arevalo et al., (1993), the primers MP1L and MP3H, which amplify a fragment of $70 \mathrm{bp}$ of kDNA from parasites of the Leishmania (Viannia) subgenus, as well as being very sensitive, have been successfully tested for the diagnosis and detection of sandflies naturally infected with promastigotes.
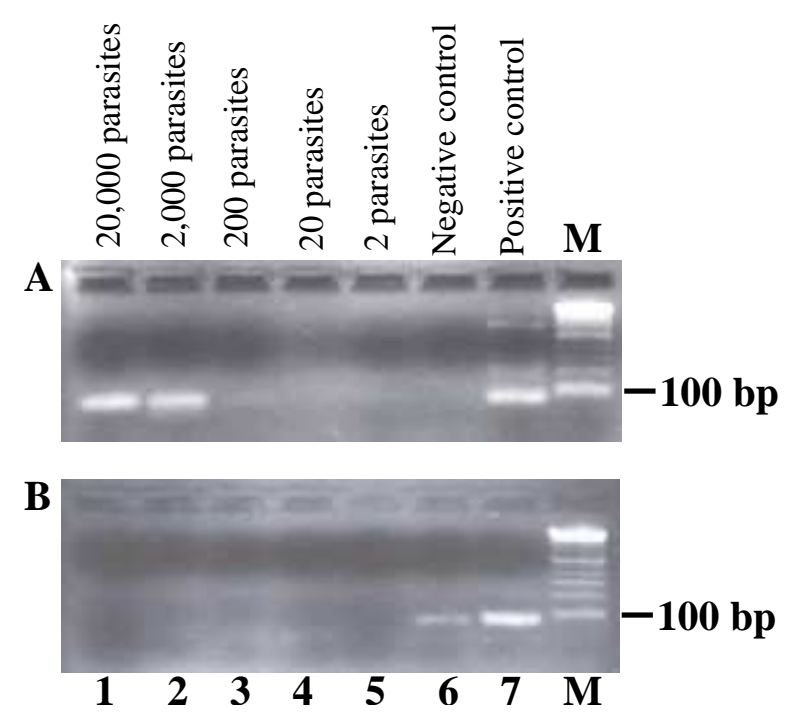

Figure 1 - Representative gel showing a $70 \mathrm{bp}$ fragment of the k-DNA minicircle region of Leishmania (Viannia) subgenus, amplified by polymerase chain reaction using MP1L/MP3H primers.

A - Polymerase chain reaction sensibility using DNA extracted by the guanidine isothiocyanatephenol method and using MP1L/MP3H primers. Different concentrations of Leishmania (Viannia) braziliensis were added to the sandfly pools, the DNA was extracted and used as target DNA. M, Molecular weight standard.

B - Lanes 1, 2, 3 and 4, negative sample sandfly pools; lane 5, negative control (PCR reaction mixture); lane 6, positive control of extraction; lane 7, positive control [DNA extracted from Leishmania (Viannia) braziliensis promastigotes]. M, Molecular weight standard.

Numerous studies carried out in Brazil have shown the difficulties involved in detecting Leishmania in naturally infected sandflies. Queiroz et al., (1994), in the State of Ceará, reported a natural infection rate of $0.42 \%(44 / 10,612)$ of $N$. whitmani $(1.13 \%)$, M. migonei (0.30\%), Psychodopygus wellcomei $(0.06 \%)$ and Psathyromyia shannoni $(0.16 \%)$. Galati et al., (1996), reported only $0.15 \%$ (1/680) in the specimens of $N$. whitmani infected with the promastigote forms in the State of Mato Grosso do Sul. Although the isolation and characterization of the parasite was not possible, the presence of the parasite in the hindgut and midgut suggested the infection by Le. braziliensis. Silva and Grünewald (1999), in the State of Rio Grande do Sul, found 3 females naturally infected with Leishmania 
(Viannia), 2 specimens of $P$. pessoai and 1 of Pintomyia misionensis, among 920 sandflies dissected. Feitosa and Castellón (2004), in the State of Amazonas, found no natural infection in 375 dissected females of 12 sandfly species, the majority of which were Nyssomyia umbratilis. In the State of São Paulo, Silva and Gomes (2001) found no natural infection by the flagellates in 5,448 dissected females, the majority $(97.1 \%)$ of which were Nyssomyia intermedia, confirming the natural tendency of a low rate of the infection for this species, despite the simultaneous report of high sandfly densities and outbreaks of the ACL.

While the dissections carried out on $N$. intermedia by Silva and Gomes (2001) did not fulfill one of the requirements for the vectorial incrimination (transmission from the vector to a hamster), proposed by Killick-Kendrick and Ward (1981), the experimental infections of this sandfly demonstrated its susceptibility to Le. braziliensis strains and their localization in the digestive tract. This fact, together with the epidemiology of the ACL, suggested that the sandflies of the $N$. intermedia s.l. complex could play an important role in the epidemiology of leishmaniasis. It is worth noting that the $N$. intermedia complex consists of the species $N$. intermedia s. str. and $N$. neivai (Marcondes, 1996).

Freitas et al., (2002), in the State of Amapá, found 60 females naturally infected by the flagellates, compatible with Le. guyanensis, among 511 dissected sandflies of the species: N. umbratilis (56/211), N. whitmani (1/6), Lutzomyia spathotrichia (1/3) and Psathyromyia dendrophyla (2/14). In the State of Bahia, Miranda et al., (2002) found 30 pools (of 10 to 20 females) infected by Le. braziliensis among 335 sandflies, concluding that if in each positive pool one sandfly was infected, $0.4 \%$ of all the insects were infected. The most frequent species found by Miranda et al., (2002) were $N$. whitmani $(92.8 \%)$ and $N$. intermedia $(6.9 \%)$.

In Adrianópolis municipality, in Paraná State, De Castro et al., (2005) detected no infection by Leishmania in 2,559 dissected females of $N$. intermedia (2,530), M. migonei (11), P. fischeri (15) and N. whitmani (3). Pita-Pereira et al., (2005) in the State of Rio de Janeiro analyzed 40 pools of the females by the multiplex PCR and hybridization and found Le. braziliensis in $N$. intermedia (5/32) and M. migonei (3/5), concluding that $2 \%$ of the insects were infected.
Naturally infected sandflies have also been found in other South American countries. In Ecuador, Furuya et al., (1998) found Le. equatorensis promastigotes in 6 of 61 dissected female specimens of Lutzomyia hartmanni. Again in Ecuador, Kato et al., (2005) found 5 Lutzomyia ayacuchensis females infected by Le. mexicana out of the 143 dissected and detected 6 infected females among 183 by the PCR. In Peru, Pérez et al., (1994) grouped 5,861 recently fed females into 713 pools, of which $8(0.14 \%)$ were infected by Leishmania spp. The infected species were Pintomyia verrucarum (6 pools) and Lutzomyia peruensis (2 pools). In Venezuela, Jorquera et al., (2005), using multiplex PCR, found 8 out of 51 sandfly pools (of 2 to 12 females) infected by Leishmania spp., estimating that $1.5 \%$ of Pintomyia ovallesi and $0.64 \%$ of Lutzomyia gomezi were infected. Again in Venezuela, Rodriguez et al., (1999), of a total of 2,700 dissected females, found 65 infected by the flagellates and isolated Le. braziliensis from 2 specimens of L. gomezi and 3 from Psychodopygus panamensis.

Studies of Leishmania isolation from the wild mammals have shown that the infection rates vary greatly (Lainson et al., 1981; Alexander et al., 1998; Brandão-Filho et al., 2003; De Castro et al., 2005; Loyola et al., 1988), which, together with the low infection rate of sandflies, hinder the enzootic cycle of the various species of Leishmania and their transmission to humans.

Considering the facts that $N$. neivai was the predominant species of sandfly in the Recanto Marista, where autochthonous cases of the ACL had occurred, the role of this species in the Leishmania transmission could not be underestimated, in spite of none infected female was found among 1,853 dissected. In such quantity of the dissected insects, at least one infected female $(0.02 \%)$ would have been expected considering the lower infection rate reported by Queiroz et al., (2002), who detected $0.06 \%$ of infected $P$. wellcomei females among the 5,278 dissected.

The absence of the natural infection in the sandfly species dissected in this study could be partially explained by the dissection of the nulliparous females, low number of the natural reservoirs of Leishmania and by the fact some of the collections were carried out close to the hen houses that were constructed to act as zooprophylatic barriers in the Recanto Marista (Teodoro et al., 2003a). 
According to Alexander et al., (2002), an existing infection might be eliminated when the sandflies took a second blood meal from the chickens. The dissection of the female sandflies collected in the hen houses was interrupted to avoid any possible interference in the detection of natural infection. Although no naturally infected sandflies were found, either by the dissection or PCR in the localities studied, the environmental conditions, the high sandfly density and the occurrence of human cases of ACL in the north of Paraná indicated the persistence of the enzootic cycle of Leishmania in the state.

\section{ACKNOWLEDGMENTS}

This work was financially supported by the National Council of Research (CNPq) and Araucária Foundation. We thank to Dr. Eunice A. Bianchi Galati and Dr. Maria Valdrinez Campana Lonardoni, for suggestions and revision, to Dr. Edelberto Santos Dias for providing the HP trap, to the administrative authorities of Recanto Marista and the Secretary of Agriculture and Environment of Maringá and to Ademir José Scodro for help with fieldwork.

\section{RESUMO}

Procurou-se verificar a ocorrência de flebotomíneos naturalmente infectados por Leishmania. Estes insetos foram coletados com armadilhas luminosas de Falcão, Shannon e HP, nos municípios de Doutor Camargo e Maringá, de novembro de 2004 a outubro de 2005. Coletaramse 11.033 flebotomíneos em Doutor Camargo e destes 2.133 fêmeas foram dissecadas, especialmente de Nyssomyia neivai $(86,87 \%)$. Em Maringá coletaram-se 136 flebotomíneos, dos quais foram dissecadas 79 fêmeas de $N$. whitmani e 1 Migonemyia migonei. Parte das fêmeas dissecadas foi armazenada em pools de 10 espécimes. A PCR, utilizando os iniciadores MP1L/MP3H, foi realizada em 1.190 fêmeas de $N$. neivai e 190 de N. whitmani de Doutor Camargo e 30 N. whitmani de Maringá. Não se constatou a infecção natural por Leishmania pelos métodos utilizados. Estes resultados indicam que é baixa a taxa de infecção natural de flebotomíneos por Leishmania, corroborando outros trabalhos realizados em áreas endêmicas de LTA, inclusive no Paraná.

\section{REFERENCES}

Alexander B.; Carvalho R.L.; Mccallum H. and Pereira M.H. (2002), Domestic chicken (Gallus gallus) in the epidemiology of urban leishmaniasis in Brazil. Emerg Infect Dis., 8, 1480-1485.

Alexander B.; Lozano C.; Barker D.C.; McCann S.H. and Adler G.H. (1998), Detection of Leishmania (Viannia) braziliensis complex in wild mammals from Colombian coffee plantations by PCR. Acta Trop., 69, 41-50.

Aguiar G.M. and Medeiros W.M. (2003), Distribuição regional e hábitats das espécies de flebotomíneos do Brasil. In-Flebotomíneos do Brasil, eds. E.F. Rangel, R. Lainson, Fiocruz, Rio de Janeiro, p. 207-256.

Arevalo J.; Ingá R. and Lopez M. (1993), Polymerase Chain Reaction. Detection of Leishmania braziliensis. In-Diagnostic Molecular Microbiology: Principles and Applications, eds. D.H Persing, F.C. Penover, T.F Smith, T.J White. American Society of Microbiology, Washington, p. 456-461.

Aransay A.; Scoulica E. and Tselentis Y. (2000), Detection and identification of Leishmania DNA within naturally infected sand flies by seminested PCR on minicircle kinetoplastic DNA. Appl Environ Microbiol., 66, 1933-1938.

Armijos R.X.; Weigel M.M.; Izurieta R.; Racines J.; Zurita C.; Herrera W. and Vega M. (1997), The epidemiology of cutaneous leishmaniasis in subtropical Ecuador. Trop Med Int Health., 2, 140152.

Brandão-Filho S.P.; Brito M.E.; Carvalho F.G.; Ishikawa E.A.; Cupolilo E.; Floeter-Winter L. and Shaw J.J. (2003), Wild and synanthropic hosts of Leishmania (Viannia) braziliensis in the endemic cutaneous leishmaniasis locality of Amaraji, Pernambuco State, Brazil. Trans $R$ Soc Trop Med Hyg., 97, 291-296.

Cabrera O.L.; Munstermann L.E.; Cárdenas R.; Gutiérrez R. and Ferro C. (2002), Definición de las condiciones de temperatura y almacenamiento adecuadas en la detección de ADN de Leishmania por PCR em flebotominos. Biomédica, 22, 296-302.

De Castro E.A.; Luz E.; Telles F.Q.; Pandey A.; Biseto A.; Dinaiski M.; Sbalqueiro I. and Thomaz-Soccol V. (2005), Eco-epidemiological survey of Leishmania (Viannia) braziliensis american cutaneous and mucocutaneous leishmaniasis in Ribeira Valley River, Parana State, Brazil. Acta Trop., 93,141-149.

Chomczynski P. and Sacchi N. (1987), Single-step method of RNA isolation by acid guanidinium thiocyanate-phenol-chloroform extraction. Anal Biochem., 162, 156-159. 
Feitosa M.A.C. and Castellon E.G. (2004), Sand fly faune (Diptera: Psychodidae) in forest fragments around housing complexes in the Manaus municipality, Amazonas Brazil: II. Horizontal stratification. Acta Amaz., 34, 121-127.

Freitas R.A.; Naiff R.D. and Barrett T.V. (2002), Species diversity and flagellate infections in the sand fly fauna near Porto Grande, State of Amapá, Brazil (Diptera: Psychodidae. Kinetoplastida: Trypanosomatidae). Mem Inst Oswaldo Cruz, 97, 5359.

Furuya M.; Motonari S.; Akimaru Y.; Mimori T.; Gomez E.A. and Hashiguchi Y. (1998), Natural infection of Lutzomyia hartmanni with Leishmania (V.) equatorensis in Ecuador. Parasitol Int., 47, 121126.

Galati E.A.B.; Nunes V.L.B.; Dorval M.E.C.; Oshiro E.T.; Cristaldo G.; Espindola M.A.; Rocha H.C. and Garcia W.B. (1996), Estudo dos flebotomíneos (Diptera, Psychodidae), em área de Leishmaniose tegumentar, no Estado de Mato Grosso do Sul, Brasil. Rev Saúde Pública, 30, 115-128.

Galati E.A.B. (2003), Morfologia e Taxonomia. InFlebotomíneos do Brasil, eds. E.F, Rangel, R. Lainson. Fiocruz, Rio de Janeiro, pp. 23-51

Jorquera A.; Gonzalez R.; Marchán-Marcano E.; Milagros O. and Matos M. (2005), Multiplex-PCR for detection of natural Leishmania infection in Lutzomyia spp. captured in an endemic region for cutaneous leishmaniasis in state of Sucre, Venezuela. Mem Inst Oswaldo Cruz, 100, 45-48.

Kato H.; Uezato H.; Katakura K.; Calvopiña M.; Marco J.D.; Barroso P.A.; Gomez E.A.; Mimori T.; Korenaga M.; Iwata H.; Nonaka S. and Hashigushi Y. (2005), Detection and identification of Leishmania species within naturally infected sand flies in the andean areas of Ecuador by a polymerase chain reaction. Am J Trop Med Hyg., 72, 87-93.

Killick-Kendrick R. and Ward R.D. (1981), Ecology of Leishmania. Parasitology, 82, 143-152.

King R.J.; Campbell-Lendrum D.H. and Davies C.R. (2004), Predicting geographic variation in cutaneous leishmaniasis, Colombia. Emerg Infect Dis., 10, 598607.

Lainson R. (1997), On Leishmania enriettii and Other enigmatic Leishmania species of the neotropics. Mem Inst Oswaldo Cruz, 92, 377-387.

Lainson R.; Shaw J.J.; Ready P.D.; Miles M.A. and Povoa M. (1981), Leishmaniasis in Brazil: XVI. Isolation and identification of Leishmania species from sandflies, wild mammals and man in north Para State, with particular reference to L. braziliensis guyanensis causative agent of "pian-bois". Trans $R$ Soc Trop Med Hyg., 75, 530-536.
Lima A.P.; Minelli L.; Comunello E. and Teodoro U. (2002), Distribuição da leishmaniose tegumentar por imagens de sensoreamento remoto orbital, no Estado do Paraná, Sul do Brasil. An Bras Dermatol. 77, 681692.

Lonardoni M.V.C.; Teodoro U.; Arraes S.M.A.A.; Silveira T.G.V.; Bertolini D.A.; Ishikawa E.A.Y. and Shaw J.J. (1993), Nota sobre leishmaniose canina no noroeste do Estado do Paraná, sul do Brasil. Rev Saúde Pública, 27, 378-379.

Lopez M.; Inga R.; Cangalaya M.; Echevarria J.; Llanos-Cuentas A.; Orrego C. and Arevalo J. (1993), Diagnosis of Leishmania using the polymerase chain reaction: a simplified procedure for field work. Am J Trop Med Hyg., 49, 348-356.

Loyola E.A.; Alzate A.; Sanchez A. and Gonzalez A. (1988), Epidemiology of natural focus of Leishmania braziliensis in the Pacific lowlands of Colombia. III. Natural infections in wild mammals. Trans $R$ Soc Trop Med Hyg., 82, 406-408

Luz E.; Membrive N.; Castro E.A.; Dereure J.; Pratlong J.; Dedet A.; Pandey A.; Thomaz-Soccol V. (2000), Lutzomyia whitmani (Diptera: Psychodidae) as vector of Leishmania (V.) braziliensis in Paraná State, Southern Brazil. Ann Trop Med Parasitol., 94, 623631.

Marcondes C.B. (1996), Redescription of Lutzomyia (Nyssomyia) intermedia (Lutz and Neiva, 1912), and resurrection of L. neivai (Pinto, 1926) (Diptera, Psychodidae, Phlebotominae). Mem Inst Oswaldo Cruz, 97, 457-462.

Membrive N.A.; Rodrigues G.; Membrive U.; Monteiro W.M.; Neitzke H.C.; Lonardoni M.V.C.; Silveira T.G.V. and Teodoro U. (2004), Flebotomíneos de municípios do Norte do Estado do Paraná, sul do Brasil. Entomol Vect., 11, 673-680.

Michalsky É.M.; Fortes-Dias C.L.; Pimenta P.F.P.; Secundino N.F.C. and Dias E.S. (2002), Avaliação da PCR na investigação de Leishmania spp em flebotomíneos experimentalmente infectados (Diptera: Psychodidae: Phlebotominae). Rev Inst Med Trop São Paulo, 44, 255-259.

Ministério da Saúde (2005), http.//dtr2001.saude.gov.br/svs/epi/situacao_doencas/lta.p df (acessed in 8/4/2005).

Miranda J.C.; Reis E.; Schriefer A.; Gonçalves M.; Reis M.G.; Carvalho L.; Fernandes O.; Barral-Netto M. and Barral A. (2002), Frequency of infection of Lutzomyia Phlebotomines with Leishmania braziliensis in a Brazilian endemic area as assessed by pinpoint capture and polymerase chain reaction. Mem Inst Oswaldo Cruz, 97, 185-188. 
Pérez E.; Ogusuku E.; Inga R.; López M.; Monje J.; Paz L.; Nieto E.; Arevalo J. and Guerra U. (1994), Natural Leishmania infection of Lutzomyia spp. in Peru. Trans $R$ Soc Trop Med Hyg., 88, 161-164.

Pita-Pereira D.; Alves C.R.; Souza M.B.; Brazil R.P.; Bertho A.L.; Barbosa A.F. and Britto C.C. (2005), Identification of naturally infected Lutzomyia intermedia and Lutzomyia migonei with Leishmania (Viannia) braziliensis in Rio de Janeiro (Brazil) revealed by a PCR multiplex non-isotopic hybridisation assay. Trans $R$ Soc Trop Med Hyg., 99, 905-913.

Pugedo H.; Barata R.A.; França-Silva J.C.; Silva J.C. and Dias E.S. (2005), HP: um modelo aprimorado de armadilha luminosa de sucção para a captura de pequenos insetos. Rev Soc Bras Med Trop., 38, 7072.

Queiroz R.; Vasconcelos I.A.B.; Vasconcelos A.W.; Pessoa F.A.C.; Sousa R.N. and David J.R. (1994), Cutaneous leishmaniasis in Ceará in Northeastern Brazil: incrimination of Lutzomyia whitmani (Diptera: Psychodidae) as a vector of Leishmania braziliensis in Baturité municipality. Am J Trop Med Hyg., 50, 693-698.

Rodriguez N.; Aguilar C.M.; Barrios M.A. and Barker D.C. (1999), Detection of Leishmania braziliensis in naturally infected sandflies by the polymerase chain reaction. Trans $R$ Soc Trop Med Hyg., 93, 47-49.

Silva A.C. and Gomes A.C. (2001), Estudo da competência vetorial de Lutzomyia intermedia (Lutz and Neiva, 1912) para Leishmania (Viannia) braziliensis, Vianna, 1911. Rev Soc Bras Med Trop., 34, 187-191.

Silva O.S. and Grunewald J. (1999), Contribution to the sand fly fauna (Diptera: Phlebotominae) of Rio Grande do Sul, Brazil and Leishmania (Viannia) infections. Mem Inst Oswaldo Cruz, 94, 579-582.

Silveira T.G.V.; Arraes S.M.A.A.; Bertolini D.A.; Teodoro U.; Lonardoni M.V.C.; Roberto A.C.B.S.; Ramos M.; Nerilo Sobrinho A.; Ishikawa E. and Shaw J.J. (1999), Observações sobre o diagnóstico laboratorial e a epidemiologia da leishmaniose tegumentar no Estado do Paraná, sul do Brasil. Rev Soc Bras Med Trop., 32, 413-423.
Teodoro U.; Silveira T.G.V.; Santos D.R.; Santos E.S.; Santos A.R.; Oliveira O. and Kühl J.B. (2001a). Frequiência da fauna de flebotomíneos no domicílio e em abrigos de animais domésticos no peridomicílio, nos municípios de Cianorte e Doutor Camargo Estado do Paraná - Brasil. Rev Patol Trop., 30, 209233.

Teodoro U.; Silveira T.G.V.; Santos D.R.; Santos E.S.; Santos A.R.; Oliveira O.; Kühl J.B. and Alberton D. (2003a), Influência da reorganização, da limpeza do peridomicílio e da desinsetização de edificações na densidade populacional de flebotomíneos, no município de Doutor Camargo, Estado do Paraná, Brasil. Cad Saúde Pública, 19, 1801-1813.

Teodoro U.; Alberton D.; Kühl J.B.; Santos E.S.; Santos D.R.; Santos A.R.; Oliveira O.; Silveira T.G.V. and Lonardoni M.V.C. (2003b), Ecologia de Lutzomyia (Nyssomyia) whitmani (Antunes and Coutinho, 1939) (Diptera, Psychodidae) em área urbana no sul do Brasil. Rev Saúde Pública, 37, 651656.

Teodoro U.; Thomaz-Soccol V.; Kühl J.B.; Santos D.R.; Santos E.S.; Santos A.R.; Abbas M. and Dias A.C. (2004), Reorganization and cleaness of peridomiciliar area to control sand flies (Diptera, Psychodidae, Phlebotominae) in South Brazil. Braz Arch Biol Technol., 47, 205-212.

World Health Organization (WHO) (2005), http://www.who.int/mediacentre/factsheets/fs116/en/. Acessed in 10/31/2005. 
PÁGINA

EM

BRANCO 